ARTICLE

Received 25 Nov 2015 | Accepted 25 Aug 2016 | Published 20 Sep 2016

\title{
To the lighthouse revisited: the art economy in Mary Gordon's Spending
}

Yu-chen $\operatorname{Lin}^{1}$

\begin{abstract}
This essay explores Virginia Woolf's legacy to Mary Gordon's Spending. More than a response to Woolf's vision of a monetary gift to facilitate woman's creativity, Gordon's novel also engages To the Lighthouse in its representation of a woman painter coming to terms with her talent. Equally important, however, is the difference between the two works, as unhappiness about her lost possibilities marks the heroine's artistic impasse in Woolf's novel, whereas pleasure over extravagant gifts characterizes the female protagonist's progress toward success in Gordon's text. By re-visioning Woolf's female artist in want in 1910s-1920s England into a woman painter in plenitude in 1990s consumerist America, Gordon's happiness narrative delineates the possibility opened up by her unhappy predecessor. This article is published as part of a collection on gender studies.
\end{abstract}

\footnotetext{
${ }^{1}$ Department of Foreign Languages and Literature, National Sun Yat-sen University, Kaohsiung, Taiwan
} 
riginating from a desire to write a "serious erotic novella" at her British publisher's suggestion (Schuessler, 1998: 46), Mary Gordon's Spending (1998) has nonetheless been characterized as a "fantasy", a feature triggering mixed reception. The author's intention notwithstanding, unfavourable reviews primarily target its lack of seriousness. Bell (1998: 28), for instance, reformulates this novel as "The Unbearable Lightness of Being", in parody of Milan Kundera, for its "limited ambitions and effects", a formula coinciding with Corrigan's (1998) critique that Gordon's "vision of an earthly paradise ... gives us all the unbearable lightness we can bear" (31). By contrast, Smith (1998) appreciates its "witty and graphic fantasy". Other sympathetic reviewers further discern its seriousness underneath its façade of levity. The reviewer for the Publishers Weekly (1997), in particular, praises Gordon for her courage to be "unfashionable" by creating a lucky heroine through whom she poses serious questions about art, money and gender relations (50).

Among other things, this controversy points to a divided attitude towards happiness associated with fantasy: it is held suspect in contemporary serious literature despite its value in the human experience. A story surrounding a happy woman artist, in particular, verges on the counterintuitive; it brings to mind Virginia Woolf s observation, in her critical essays, of frustration and anger prevailing in woman's writing. Indeed, as Hawley (1998: 20) suggests, Spending seems to be responding to Woolf's vision of an alternative economy, in which the female artist is given a large sum of money and a room of her own so that she can produce masterpieces comparable to her male counterpart's. More than a response to Woolf's vision of a monetary gift to facilitate woman's creativity, I will argue, Gordon's novel specifically engages To the Lighthouse in its representation of a woman painter coming to terms with her talent and in its recourse to the fairy tale, a genre characterized by a celebration of contingence, to express this concern. Equally important, however, is the difference in style and cultural background between the two authors. In view of their difference in shared concerns and expressions, I contend that unhappiness about lost opportunities marks the heroine's artistic impasse in Woolf's novel, whereas pleasure obtained from extravagant gifts characterizes the female protagonist's progress toward success in Gordon's text. By revisioning Woolfs female artist in want in 1910s-1920s England into a woman painter in plenitude in 1990s consumerist America, Gordon's fantasy inscribes a possibility for a feminist triumph over patriarchal tradition of art. As the interactive dynamics between these two writers come into clearer focus when viewed through the theoretical lens of the gift and affects, I will make references to these two theories pertaining to art in the course of exploring Woolfs legacy to Spending.

\section{Women's art, economy, ethics}

In The Gift: The Form and Reason for Exchange in Archaic Societies (1950), Marcel Mauss (1990) delineates three essential features of gift transactions: the obligation to give, to receive and to reciprocate (39). What is more, he suggests that the object involved in gift practices is one between souls, thus to make a gift is to "make a present of some part of oneself" (12). This view is anticipated by Ralph Waldo Emerson, who suggests that the gift is often superfluous since it is nothing but a part of the self (25). This explains why it tends to be pleasurable rather than useful or valuable. Fruits and flowers, by this standard, make good gifts, whereas jewellery is usually an excuse for the self (25-26), and money can be offensive, except from family members, because it reminds one of business transactions that violate the spirit of gifting in the absence of a well-intentioned self.
Lewis Hyde extends the rapport between self and other and the aversion to the market in gifting to his category of art economy. In The Gift: Imagination and the Erotic Life of Property (1979), he distinguishes between the gift and the market in terms of eros and logos: the former is emotional (or erotic) in that it joins self and other, whereas the latter is rational (or logical) since it requires the detachment of self from other (155). A work of art, he proposes, is essentially more erotic than logical. As a gift, however, art is different from its quotidian counterpart in form and passage. It begins with the initial gift of talent, an "erotic state" bestowed on the self, which allows the artist to perceive the "underlying unity of things" (163). This gift generates the secondary gift from the artist, who undertakes labour of gratitude to produce the tertiary gift, the finished artwork offering to the audience and at the same time directing toward its source-the primary gift of talented state (190-191). The spirit of gifting in Hyde's economy, in this view, is increase and dispersion within the art community, where the gift circulates among primary (the artist), secondary (sources of inspiration), and tertiary recipients (the audience). Although Hyde believes that art should be untouched by the market to ensure its aesthetic integrity (158-159), he admits that financial security is beneficial to artistic creativity. To achieve this end the artist can take second jobs, seek patronage, or place his/her work on the market. Of the three options, the last one is the most favourable to the artist since it is less involved with the market (275).

Virginia Woolf would have been delighted by Hyde's anatomy of art economy had she lived to read his book even though her concern is more gender-specific and thus emotionally charged than Hyde's. Indeed, A Room of One's Own (1989), Woolf's history (or its lack thereof) of woman's writing, can be read as her vision of woman's art economy. Like Hyde, she considers talent as an endowed gift, except that this gift is a curse to the woman writer in that it is not attended by the erotic rapport from society to sustain it. In fact, it is regarded as a transgression of her assigned role-an object of man's will rather than a subject having a will of her own. Always anxious about monetary matters probably out of resentment for Leslie Stephen's "irrational meanness" to his daughters about housekeeping and education costs (Lee, 145-146), Woolf associates this problem with woman's financial status. She argues that in the absence of financial resources as well as a woman's literary tradition to fall back on, the woman writer stands out as an anomaly in patriarchal economy where her talent is not acknowledged. As a result, the productions of creative women-if they survive the curse of their talent at all-are almost always tinged with anger, while masterpieces by male writers are largely free from this symptom. In view of the deleterious effects of economic dependency on woman's creativity, Woolf proposes a counter-economy in which woman is independent financially: she has to have 500 pounds a year and a room of her own where she can concentrate on writing. Although Woolf's income as a writer amounted to this "magic number" 3 years before A Room of One's Own was first published (Lee, 1999: 550), she does not specify the source of the fund essential to woman's art. This silence leads Gordon, editor of the 1989 Harvest edition of A Room of One's Own, to speculate that the money Woolf has in mind "cannot be earned; it must come to the writer in the form of a windfall or a legacy, or it will bring with it attachments, obligations" (Gordon, 1989: viii). In other words, Woolf's female art economy, as Gordon understands it, is built on an unconditional gift-a pure gift which does not require reciprocity (Malinowski, 1922: 177-180)—or a conditional gift through patronage. Either way, it is associated with hap -luck, chance, fortune-which is the etymology of happiness (Ahmed, 2010: 22). 
Envisioning a monetary gift that allows the artist to answer the call of her gift of talent, Gordon's Woolf is quick to idealize patronage as an unconditional gift, totally suppressing the fact that historically patronage involves power relations, which threaten artistic autonomy and the spirit of the gift. Indeed, this economy dictates a hierarchical patron-client relation: the client was expected to show formal or behavioural deference to the patron (Gundersheimer, 1981: 13-16). Aesthetic deference was also required, in the form of guild rules in the later Middle Ages (Janeson, 1981: 344) and detailed instructions from the patron or advice from the "humanist adviser" associated with the patron (Hope, 1981: 296), leading to the emergence of regional schools of art (Gundersheimer, 1981: 17). What is more, the patron-client relation in art patronage was not immutable, as competition existed between rivals and their client groups. Under such a circumstance, established artists experiencing status dissonance would take new "employment" in the hope of obtaining rewards commensurate with merits, and patrons might employ more competent talents from other areas to replace artists under their protection. In other words, patronage does not merely reflect personal tastes or passions (Hope, 1981: 343); it also demonstrates patterns of "rational calculation" (Gundersheimer, 1981: 18 ) in both parties, patterns akin to those of business deals.

This form of economy flourished in pre-industrial Europe (Gundersheimer 3), but transformed into a more egalitarian artist-patron relation and commodification of the art with the rise of the middle class in Victorian England. Still, it retained the tension between the two parties as the artist often outclassed the patron, a class shift which disrupted the power relation in the classical patronage. As a consequence, mutual resentment was not unusual even in the most intimate patronage like the PreRaphaelites, as the avant-garde artist found it hard to maintain artistic independence from their middle-class patrons, whose preference for mimetic representations of daily life and utilitarian views on art led to the rise of the English school of art. In addition, with more options to translate their creative products into money, artists became more skilful in negotiating their financial benefits by raising the price of their products, working for more than one patron, producing duplicates of their works, to name but a few (Macleod, 1996).

All in all, patronage is more a business deal than a gift practice, thereby making Woolfs art economy for women highly problematic from Gordon's perspective. Even more tellingly, Woolf chooses not to address this problem even though she must have been aware of it from the unhappy accounts of her greataunt, Sara Prinsep, whose husband's good will to the artist was abused (Macleod, 1996: 300-301). Nor does the "logical" transaction of patronage ensure the emotional interaction essential to woman's "gifted state" given patriarchal denigration of woman's creativity. Symptomatically, this gap remains unbridged even though it triggers Woolf's vision in the first place. The only way out seems to lie in homoerotic relation among women. This possibility explains why Woolf praises Life's Adventure, Mary Carmichael's novel about woman's friendship. Despite the promise of happiness brought about by the emotional attachment between two female scientists, however, Woolf is quick to censor this lesbian writing by calling attention to its lack of skills, followed by her apprehension that she might invite harsh critiques on her feminism and latent lesbianism (Lee, 1999: 520). Even more notably, Woolf's self-censorship takes a dramatic reversal in her upbeat conclusion, reversal intended to encourage young women who "seem[ed] to get fearfully depressed" (qtd. in Gordon, 1989: xiv). In other words, she employs a celebratory tone to suppress the reality that her utopia rests on an impossible gift economy. Her female art economy, in this view, is an unfulfilled hope for an alternative world, indeed a thwarted fantasy since it does not live up to the promise of happiness through the right path (Ahmed, 2010: 208). This gap helps explain why Woolf's vision does not fully exempt herself from anger. As Gordon (1989) suggests, despite her interest in the subject, Woolf feels "cheated" in her education and on behalf of her predecessors, making her "as angry ... as Charlotte Brontë" (xiii).

Woolf's (1955) anger about the woman artist's mishap is most palpable in To the Lighthouse, where Lily Briscoe, an aspiring painter and Woolf's alter ego, has never moved beyond her gifted state since she is deprived of erotic rapport essential to its sustenance. First of all, she is constantly challenged by her imaginary audience, incarnated by Charles Tansley, a misogynist who denigrates woman's creativity: "Women can't paint, women can't write ..." (Woolf, 1955: 75; original ellipsis). Her diffidence is reinforced by her divergence from the fashionable impressionist tradition championed by a male painter, Paunceforte. The absence of a tradition for her to rest on might be compensated by intimacy with Mrs. Ramsay, for whom Lily has great passion. Nevertheless, Mrs. Ramsay turns out to be an unsuspecting muse, thereby thwarting the erotic rapport Lily desperately needs, even though she graciously accords Lily's request to sit for the younger woman at her family summer house in the Isle of Skye. In fact, for all her impulse to give gifts to the needy and to cater to men's demand, she consistently disregards Lily's needs. Complicit with patriarchal values despite her marital woes ("she [Mrs. Ramsay] was driven on, too quickly she knew, almost as if it were an escape for her too, to say that people must marry") (Woolf, 1955: 92-93), she unreflectively believes in marriage as the path to happiness, and judges Lily in terms of marriage marketability ("With her [Lily's] little Chinese eyes and her puckered-up face, she [Lily] would never marry") (Woolf, 1955: 29). In her good will, she wishes for Lily's marriage with William Bankes, but her wish turns out to be as domineering as that of the Fisherman's wife in the fairy tale she reads to her son James: "Wishing to dominate, wishing to interfere, making people do what she [Mrs. Ramsay] wished-that was the charge against her ..." (Woolf, 1955: 88). By wishing for the marvel of a creative woman subjugated to marriage, she is the accomplice of the compulsory gender role defined by patriarchy. It is not surprising, therefore, that she sides with Charles Tansley's view toward Lily's art ("one could not take her [Lily's] painting very seriously”) (Woolf, 1955: 29).

Fully aware of her marginalization in art economy, Lily foresees the fate of her painting: it "would never be seen; never be hung even" (Woolf, 1955: 75); that is, it would never circulate among her viewers either as the fruit of her talent or as a marketable commodity to engage the interest of dealers, collectors, or patrons. Torn between her desire to answer the call of her talent and her awareness of her deviation from the mainstream art tradition ("She would not have considered it honest to tamper with the bright violet and the staring white since she saw them like that, fashionable though it was ... to see everything pale, elegant, semitransparent") (Woolf, 1955: 31-32), she is highly self-conscious when someone approaches her workin-progress (Woolf, 1955: 30). In the absence of emotional support in the form of art tradition and sympathetic audiences, Lily abandons her painting altogether, and resumes it as an act of mourning and a belated tribute to Mrs. Ramsay, who died suddenly ten years ago. The novel concludes with Lily standing before her finished work, fatigued by her tremendous effort to put her vision on canvass and crying bitterly over her loss: "It was done; it was finished .... I have had my vision" (Woolf, 1955: 310). Even though she has triumphed over her muse's tyrannical wish for her to marry, thereby escaping from the role of the obedient flounder in Mrs. Ramsay-the Fisherman's Wife's wry fairy tale of perfect marriage, her triumph is a pyrrhic victory: Mrs. Ramsay is dead, and her painting will be consigned to 
oblivion altogether. Her mourning of Mrs. Ramsay's loss, to borrow from Ahmed's (2010) reading of Mrs. Dalloway, is also a mourning of lost intimacies which in turn becomes lost possibilities (73).

Writing five decades after Woolf as a fledging feminist and apprentice novelist, Gordon still encountered the kind of problems delineated by her predecessor. As Woolf had been debilitated by an awareness of patriarchal denigration of woman's art, so was Gordon unnerved in 1971 by a famous male writer's analogy of woman's writing as a female bear's shit in the cave (Gordon, 1992: 148). This analogy suggests that woman's writing stems from her body in the domestic sphere, an inclination to be frowned on since it leads to trivial and thus embarrassing literary productions. Indeed, the important lesson Gordon (1992: 149) learned from American canons was "distance from the body, from the heart, but most of all, distance from the self as writer". This injunction against the body and the self was resonant with "Irish sexual Puritanism" (Gordon, 1992: 201-202), voiced by Gordon's uncle on the representation of sexuality in her first two novels, Final Payments (1978) and The Company of Women (1981): "I just want to tell you that I can't stand your books. None of us can" (Gordon, 1992: 200). Luckier than Woolf, however, Gordon enjoyed the erotic rapport with women writers, dead and alive ${ }^{1}$ who helped "banish the dark specters" (Gordon, 1992: 150) of patriarchal denigration and the attendant anger that inform Woolf's texts.

Even so, Woolf's unhappiness was still relevant in 1990s America, where pleasure is suspect despite the general ethos about the promise of happiness through personal achievements and consumption. As Gordon observes: "I feel like pleasure makes people really crazy. We're just not comfortable with it" (Schuessler, 1998: 45). In her view, pleasure largely falls into two categories: personal happiness and happiness in work. While personal happiness can be embarrassing, she suggests, it is safer when paired with happiness in work-an observation coinciding with the classical concepts of the hierarchies of happiness (Ahmed, 2010: 12). She also notes that this combination is gender specific: it is justifiable for men but not for women, who tend to be "very superstitious" about asking for both (Schuessler, 1998: 46). By fleeing from happiness in both private and public spheres, the American woman is still entrapped by the "Happy American Housewife" myth (Friedan, 1965: 19-20), a myth analogous to the Angel of the House ideology which has troubled Virginia Woolf seventy years ago, making her a "feminist killjoy" (Ahmed, 2010: 50 passim). In view of Woolf's unhappiness as a feminist, it is not surprising that Gordon likens woman's flight from double happiness to Virginia Woolf's legacy: "For women, [the restraint from happiness in work and in life is] almost like one of Virginia Woolf's ghosts that has to be put down" (Schuessler, 1998: 46).

To negotiate a way out of Woolf's delineation of the mishap surrounding creative women's gifted state and its attendant unhappiness, Gordon aspires to celebrate double pleasurehappiness in work and personal pleasure-in her serious erotica that is Spending. As she informs her interviewer: "With Spending, I wanted to write a book about pleasure in its various forms .... A Catholic writing about sex-now that's going to make a lot of Catholics nervous" (Schuessler, 1998: 45). As the title suggests, this double pleasure pivots on monetary expenditures and sexual pleasure, thereby evoking several American cultural forces during Gordon's formative years: feminist emancipation affiliated with students' activism in the 1960s and 1970s in revolt against established institutions, including capitalism, patriarchy and religion (Bennett, 1996: 9). It is to be noted that these forces are often at odds with one another, feminism and Catholicism being a troubled pair (Ruether, 2003: 8). The internal contradictions of culture, in turn, shape the oxymoronic subject position of Monica Szabo, the female protagonist-cum-narrator of Spending - a married anti-capitalist feminist Catholic artist who identifies herself with the male art tradition. In her ambivalent relation to patriarchy, she is arguably a synthesis of Lily Briscoe and Mrs. Ramsay. With this combination Gordon maps out problems uncharted by Woolf when she envisions her art economy for woman. What would happen when an emancipated feminist artist is lucky enough to enjoy unconditional patronage from a man affiliated to a capitalist trade and a rich woman who is estranged from the Catholic church for sexual transgression? How does she reconcile these contradictions? Finally, what does it take for Gordon to engineer this reconciliation? These problems are put to test in Spending, where Monica negotiates her art and life by earning her own living before she meets her patrons.

\section{Spending: desire beyond a room of one's own}

Spending is arguably a story about Monica's move from unhappiness toward happiness. A middle-aged Hungarian American Catholic, Monica is already a painter of modest success in New England before her story begins, making her a progressive version of Woolf's woman artist. Her success, however, is earned through a compromise with her marriage. Indeed, her lived experience in 1990s America is both progressive and retroactiveostensibly more liberal than that of Woolf's time, but actually retains the gender divide that Woolf has lamented. Woolf (1942: 237) characterizes domesticity as "the difficult art of family life" which constricts woman's creativity. Indeed, Mrs. Ramsay's married life presents itself as such an ordeal to Lily Briscoe that she congratulates herself on having escaped the older woman's wish for her to marry: "For at any rate ... [Lily Briscoe] need not marry, thank Heaven: she need not undergo that degradation. She was saved from dilution" (Woolf, 1955: 154). Monica's life trajectory further testifies to the validity of her predecessor's view. A radical student in the 1960s who believes in social equity in various forms, she willingly enters into marriage out of love for Roger, a script-writer, but only to find herself subordinated to the patriarchal gender ideology that has troubled Woolf at the expense of her desire to create. Juggling with her multiple roleswife, mother, art teacher-and at the same time trying to paint, Monica suffers from the double trial of domesticity and creativity. Domestic chores and creative work, after all, require totally different states of mind and circumstances (Cooperman, 1999: 44). Her situation does not improve when her twin daughters grow up. On the contrary, at the later stage of her eighteen-year marriage, she finds herself almost solely responsible for household upkeeps and domestic chores since Roger contributes less and less to the family to allow himself to be inspired (Gordon, 1998: 40). In other words, she is expected to act as her husband's "patroness" of some kind to sustain his creativity. However, her financial contribution does not earn her due appreciation from her husband. Instead, Roger demands her full attention to domesticity as well, totally ignoring her need, like his own, to stay in touch with herself in order to create. She thus becomes "a work-crazed bitch" (Gordon, 1998: 81)-as her daughter Rachel calls her after Roger-when she cannot be distracted from painting to meet his demand. When marriage turns out to be too much for her, she divorces Roger, and secures an apartment in Cape Cod, as well as a small studio in New York with her income and savings.

Having two rooms of her own, Monica is finally able to concentrate on her art when she is not teaching. By so doing she moves toward the utopian happiness in work that Woolf has dreamed of. But she desires something that is considered incompatible with feminism (Ahmed, 2010: 53): personal 
happiness, which comes from domesticity in happier circumstances. This desire for double pleasure marks her departure from her predecessors, but also proves to be impossible for a woman artist. Unlike Roger, who enjoys both domestic bliss and creativity through her labour, Monica can only articulate her desire for this double happiness through her painting entitled The Artist's Muse, a "silly" representation of happiness. Depicting an aroused man in silk boxer shorts holding a frying pan in one hand and an egg in another (Gordon, 1998: 15), this painting reveals Monica's desire for a love object who is both the source of her inspiration and the provider of her quotidian comfort. However, she is also aware that such a muse is unimaginable, as is suggested in her deliberation on the man's shorts and the frying pan, against the background of surrealist "[d]e Chirico emptiness" (Gordon, 1998: 15), instead of highlighting the man's face. This displaced focus reflects the fact that this painting is done from memory in the absence of a live model, as Monica confesses in jest to the audience of her slide show in a newly opened art gallery in Provincetown (Gordon, 1998: 16). It also points to the gender divide in the patriarchal art tradition where man figures as the producer rather than the muse. Encouraged by audience's laugh over her humorous confession, Monica goes a step further to describe the muse, modelled on herself, as a selfless nourisher who caters to the male artist's quotidian, financial and artistic needs, " a combination model, housekeeper, cook, secretary. And of course she earns money. And provides inspiration" (Gordon, 1998: 16). She concludes her description with a rhetorical question to tone down her discontent: "Where ... are the male muses?" (Gordon, 1998: 16). To her surprise, her silly question is taken seriously by one of her audience, later identified as $\mathrm{B}$, a rich Jewish American futures trader. He stands forward to exclaim, "Right here" (Gordon, 1998: 16). Even more surprising is that he takes this silly question as a wish, and grants it by offering to be her muse, and, fitting her job description, lover as well as patron. From then on the story adopts a synthetic form of realism and fairy tale, a genre coinciding with happiness for its celebration of contingency. By so doing B restores Mrs. Ramsay's wry fairy tale to the norm of the genre, as he impersonates the flounder who answers to Monica the Fisherman's wife's wish by ushering her into a wonderland far exceeding her expectation as well as Woolf's dream for woman's art, a utopia where creativity coexists with pleasure.

\section{Art, sex, money}

At first glance, silliness is almost the antithesis of unhappiness. After all, it is considered a form of worthless happiness even though its etymology carries the meaning of blessed, happy, or blissful. As Ahmed (2010: 222) suggests, however, unhappiness with injustice can be read as an emotion close to silly feelings. This view sheds light on the continuum between Woolf's protagonist and Gordon's. To the Lighthouse concludes with Lily grieving over the loss of her unwitting muse who would never receive her return gift of painting. By contrast, Spending begins with Monica's happiness with the ongoing relation with $B$, her willing muse, as is revealed in her candid, indeed almost silly reappraisal: "I must tell you, it was always about money .... Of course, it was also about sex. And since I'm a painter and it affected my life and work, you'd have to say it was about art" (Gordon, 1998: 7). As her story unfolds, he proves to be her ideal muse incarnated: a patron and a lover-nourisher. As a patron he defrays the cost for the "[s]pace and time" she requires to give her "the optimum conditions for work" (Gordon, 1998: 41), including her salary as well as spacious studios. In addition, he mixes business (as a patron) with pleasure (as a lover) by taking her to major museums in Europe and America for her to sketch the
Masters' works and to spend leisure time having fun with him. As a partner-nourisher, he feeds her with gourmet food when she is occupied with work, heartens her with sex and his company when she is too tired or frustrated to work. Finally, his postcoital lassitude inspires her Spent Men series, which elevates her modest fame to instant sensation. In other words, his offer promises to lead Monica to personal happiness as well as happiness in work. If happiness is a hope for the future, however, it also triggers anxiety since what one wants might not happen (Ahmed, 2010: 183). This is exactly what happens to Monica. As the promise of double happiness made by B's offer is what Monica desires, her luck verges on the impossible to such an extent that she is dubious about it. The gift, after all, is rarely given to a stranger except in charities; violation of this convention often provokes negative reciprocity-suspicion, retribution, to name but a few (Sahlins, 1974: 195). What is more, B's gift involves economies that do not sit comfortably together. As a result, the happiness promised by B's gift is always tinged with negative emotions.

Surprise is Monica's initial feeling about B's offer. As Derrida (1992: 146) suggests, the pleasure promised by the gift, like other forms of pleasure, is "always and first of all the pleasure of being surprised". In this view, B's offer presents itself as an ambivalent gift: it was pleasurable since it takes Monica by surprise, but this surprise is paradoxically attended by B's pre-empting statement of his purpose and method, thereby turning the surprise inside out. When Monica characterizes the muse as the artist's intimate companion, she has in mind a long-term relation fostered through time, not knowing that her expectation coincides with his. This explains why she is unprepared for B's offer to be her muse not only because she does not expect her question to be taken literally but because she does not know him at all. Probably to make up for the "lost time" B begins from scratch, once again in an unexpected way for Monica, for his preliminary is best described as courtship, if not seduction. Even more surprisingly, he informs her that he is rich, and is willing to spend money on her-not unlike the flounder's declaration of its magic power. Perfectly answering to Monica's need but too good to be true, this offer is thus both pleasurable and suspect.

The ambivalence of B's offer accounts for Monica's mixed feelings about the series of surprises in store for her. As a woman who is used to average comfort despite her love of sensual pleasures, she is delightedly surprised by B's luxurious treats even though her astonishment is tinged with unease since it offends her feminist sensibilities. At its worst, this unease even turns into fear. As Derrida (1992: 147) suggests, even though surprise causes the pleasure of the gift, it is also potentially violent since to take the other by surprise is to have a hold over the recipient. Indeed, despite her surprised delight in B's offer, Monica envisions scenarios of violence ("Being stolen from. The worst thing about it is being taken by surprise. Being shocked. Then outraged. The bereft") (Gordon, 1998: 21). Probably dazed by surprise, however, she shelves her concerns with rationales she would have dismissed as "unliberated" (Gordon, 1998: 19), and appeases her fear by probing into it ("But I don't feel stolen") (Gordon, 1998: 21). Rather, she is pleased with B's boldness, which conjures up images mixing biblical allusions with sensual pleasure: she feels both flattered as B's "chosen woman" (Gordon, 1998: 18), and aroused as a desiring Queen of Sheba sailing toward King David (Gordon, 1998: 18-19). This quasi-biblical elation culminates in the consummation of their carnal desire in B's designer house, a domestic paradise where her wish for a male muse is fulfilled.

Even though Monica's fear yields to her sexual pleasure, it resurfaces when B adopts a business-like tone to inform her that he is serious about her as a patron and a lover (Gordon, 1998: 36). Conflating possibilities that might be mutually exclusive-a 
gratuitous gift allowing her to be a full-time artist, an anachronistic patronage probably entailing her deference in exchange for financial "protection", and a love proposal-B's economy of methods frightens Monica. Her fear is complicated by the oxymoronic multiplicity of her subject position best summed up by herself: "a bad combination of obedience and rebellion" (Gordon, 1998: 212). Given the complexity of her selfhood, her response to B's equally intricate gift is ambivalent.

\section{The gift and its reciprocity}

Constituted by a feminist revolt against the patriarchal repression of woman's body and creativity, Monica's rebellious side heartedly welcomes what sensual pleasure and professional privileges B's money could buy, whereas her anti-capitalist side suspects that B's more-than-generous offer is a business transaction, which entails a repayment gravely offensive to her Catholic sensibilities - sexual favors. As a result, Monica wavers between gratitude for B's generosity as well as passion for him, and resentment towards him because as a patron he "bring[s] tincture of whoredom" into his offer despite its promise to bring "woman and art" together (Gordon, 1998: 50). Granted that her inconsistency is attributable to the ambivalence of his offer in the first place, at her worst she counteracts this ambivalence by refusing to reciprocate his generosity. This counteraction she executes on chosen fronts of selfhood. First of all, she refuses to be interested in his work for its negative association of their relation-money (Gordon, 1998: 94), and, by extension, capitalist exploitation. Instead, she calls him "Daddy Warbucks" (Gordon, 1998: 107) at moments of anger, and refers to him as "the imperialistic colonizing capitalist pig", a label B adopts in self-mockery (Gordon, 1998: 131). Refusing to know about B's other life even superficially, she also denies him access to her social circle and flees away from "the demons of female duty" (Gordon, 1998: 152) of caring for him when he suffers from debilitating back pain on the grounds that her obligation to B's patronage is to work.

Indeed, work is the most indomitable part of herself, making her relentless in withholding reciprocity to B's generosity. Instead of showing deference to her patron as is expected of a client, she bars him access to her work even when she is working in his house. Moreover, despite her pleasure in touching him as "a happy animal" when she is not working (Gordon, 1998: 105; sic passim), his body assumes a function alien to both of them when she asks him to sit for her. His offer to be her muse notwithstanding, B knows well enough that her gaze would turn his body into a site where her relentless self as an artist reigns, thereby blocking the traffic of their mutual desire. Still, B acquiesces to Monica's request out of good will. His generosity, however, does not earn her gratitude. Instead, it reinforces her impulse to resist reciprocating his generosity: "Now he was giving me something else I needed ... My gratitude needed to be doubled. I had to think about the nature of my obligation .... When I feel I ought to be grateful, I turn into a rebellious slave" (Gordon, 1998: 105).

Characterizing herself as a "rebellious slave," Monica nonetheless behaves like a totalitarian master, thereby testifying to the validity of Ralph Waldo Emerson's observation on the danger of giving: "we do not quite forgive a giver. The hand that feeds us is in some danger of being bitten" (1997: 26). Indeed, Monica becomes so irritable that she is "ready to pick a fight" with B when he arrives, and loses her usual sense of humour when he produces his mock work manual-an article which contains a list of the muse's responsibilities written by Vera Stravinsky, the famous musician's wife, when she was still married to a painter (Gordon, 1998: 106). In rage, she informs him that all she needs is the last item on the list, the "physically perfect" body (Gordon,
1998: 106). Having said so, she strips him in order to sketch him. This power struggle lasts for several months, during which time B gradually becomes frightened by his status "as a form ... an object rather than a person" to Monica (Gordon, 1998: 109), as he complains to her: "You were drawing something. Some THING. But not me. It was making me feel panicky" (Gordon, 1998: 109). He thus wants to flee from the relentless artist "so he could get his soul back. The soul he felt [Monica had] eaten up" (Gordon, 1998: 110). His panic, however, annoys Monica, who is determined not to empathize with him. As a consequence, they become angry with each other. To solve this problem she adopts the "efficient" way she often uses with her professional model: timed posing. In other words, B's task is carried out in a method akin to a business transaction even though in the depths of her heart Monica is grateful to him for his generosity (Gordon, 1998: 110).

\section{Female creativity}

Compared with her mixed response to B's gift of patronage and inspiration, her erotic rapport with her predecessors in art is consistently positive. Unlike Lily Briscoe, who is ill at ease with her talent for want of a tradition to fall back on, Monica enjoys what Duplessis (1985) calls "double consciousness" in her awareness of and oscillation between "a main and a muted position" (42). She is relaxed with her gifted state inspired by the Renaissance Masters even though she is also aware that "for most of history, no woman was allowed to do what [the Masters] did". Fully confident about herself as an artist, she does not feel qualm about her transgression; nor does she harbour hostility towards her male predecessors: "The relationship of my work to the Masters who'd gone before me wasn't hostile. There was nothing I was making fun of, no fault, either in execution or in interpretation, I was trying to show up" (Gordon, 1998: 87-88). Rather, she is confident about her contribution: "I will paint what I have seen, which is something you [the Masters] didn't" (Gordon, 1998: 88). Her idea for her major works exemplifies such a position. Originating from her carnal pleasure with $\mathrm{B}$, it nonetheless evokes classical masterpieces. B's body in postorgasmic lassitude reminds her of Jesus in Carpaccio's Meditation on Christ's Passion, which in turn triggers an alternative vision of dead Christs represented by the Masters: "Suppose all those dead Christs weren't dead, just postorgasmic?" Drawing B and Carpaccio from memory to test out this possibility, Monica has an idea for her new project: a series of paintings of postcoital men, entitled Spent Men, After the Masters, based on Italian Renaissance portraits of the dead Christ (Gordon, 1998: 55).

In contrast to Lily Briscoe, who is sure of painting "what I see" (Woolf, 1955: 32), the form of Monica's paintings does not come as readily as the content. Even though she has done preparatory work by sketching the Masters' works in major museums and by drawing $\mathrm{B}$, as a modern artist she begins with modish techniques, projecting a photograph of the Old Master's image onto her own, and photographic images of classics onto her canvas. But none of these forms relates her thought to her body, making her feel that everything she does seem "dead" (Gordon, 1998: 129). It is a female muse, uncovered from her buried memory, that helps solve this problem: Sister Imelda, her first-grade teacher, kneeling in front of the monstrance. She sees an image of "perfect concentration, perfect self-forgetfulness," which was the life she wanted, even though her focus of attention has shifted from God to the visible world (Gordon, 1998: 132). She then realizes that her paintings would synthesize "art and faith" of the past and the present into "the life of the spirit" (Gordon, 1998: 132-133). This detour to the past locks thought and body in place, thereby enabling her to represent her thought. Instead of modish 
techniques, she creates her own style which is modern and yet influenced by the Masters. What follows is a stage of high concentration on work attended by the "childish delight" of colour (Gordon, 1998: 133).

Monica's happiness in work yields the fruit of her labour, which, through the good work of Fanny, her agent, are duly put on the market to become a great success. As her paintings are inspired by her male lover and a mother figure, so is her luck complemented by a new patron, Peggy Riordan, an elderly Irish American woman who can be understood as B's double. If B evokes the enchanted prince-turned magical flounder, Peggy reminds one of the fairy godmother that Mrs. Ramsay is not. She offers Monica a commission to make up for her lost opportunity to purchase Spent Men as she finds Monica's sexualization of Christ's body addresses her disenchantment with the Catholic church which frowns on her long-term relation with her former boss (Gordon, 1998: 223). This business deal, however, turns into an intimate patronage any artist would dream about. For one thing, Peggy gives Monica full autonomy except for her initial wish to "spit in the eye of that part of the Church that thinks sex is wicked and shameful" (Gordon, 1998: 223), a wish fully according with Monica's liberal view of religion. For another, in the course of drawing Peggy for her commission, Monica begins to develop an intimate friendship with her patroness, a relation Lily has been denied. Monica often exchanges material gifts with Peggy, and is eager to share life with her by introducing B and her daughter Sara to her. She even takes the older woman to a Russian bath, a trip which gives her an idea for her next project as she observes the older woman's naked body. As Monica's patroness, muse, and an intimate friend, Peggy is not only B's female counterpart, but the kind of Mrs. Ramsay unavailable to Lily Briscoe. Feeding on her toilsome labour of representing B's body, Monica's production of Peggy's commissioned work is conceived as the end of Spent Men in its indebtedness to classical art. Conflating Peggy with Sister Imelda, she represents her patroness in the central panel, a "chaste, chastening commentary" on Jesus's "sprawling isolation" in the wings (Gordon, 1998: 230) of a full-sized Renaissance triptych. By representing Peggy as a pious Renaissance woman in God's company, Monica once again adopts double-consciousness to pay tribute to Renaissance Masters, and to rectify Peggy's wrongs from a contemporary, liberal perspective. This attempt is not lost on Peggy, who is deeply moved by Monica's finished commission.

All in all, Monica's art is negotiated through the double gift: a double-consciousness of the art tradition constituted by Masters' and her own vision, and inspiration from both male and female muses. This double luck enables her to steer away from Lily Briscoe's double frustration, a thwarted desire for her unwitting muse whose internalization of patriarchal values stumps her creativity. This gifting in art economy ultimately returns to its cause, the expenditures of the self in the monetary gift. With this shift of gifting, Monica's happiness in work moves toward her personal happiness, which involves her reciprocity of B's generosity.

\section{A hope for a Utopia}

While her commission is in progress, Peggy offers Monica a valuable apartment in central New York, not unlike a mother's bequest to her daughter, or a fairy godmother's to the virtuous heroine. This more-than-generous offer timely helps lift B from the distress for losing four million dollars in the futures trade, distress literally turning him into an impotent "spent man" (Bromberg, 1999: 33). His abjection compels Monica to inspect her impulse to resist his good will: "When B was my benefactor, I wanted to hold part of myself back from him ... It was exactly the endless benevolence I felt after he was broke. After that there was nothing I wanted to hold back" (Gordon, 1998: 239). With the barrier of money lifted, Monica goes all out to reciprocate B's generosity. Taking over the role of the magical helper to the ladin-distress, she tends to his emotional and physical needs, and helps him out by going about money matters. She sells Peggy's apartment in New York, and gives half of the money to B to restart his business. Capable of giving a monetary counter-gift, Monica can also bring herself to know about his work by requesting to visit his office. For the first time she takes a glimpse into the part of B's life which is foreign to her, and feels quite at ease with this unfamiliar scene because B seems "most alive" when he is at work (Gordon, 1998: 288), much as she is. In taking $\mathrm{B}$ as he is, she is finally in step with him in the expenditures of the self.

Happy with work and life shared with B, Monica decides to throw a party to celebrate several joyful events-the success of B's work and her own, three years of their relation, and her daughters' rites of passage (Gordon, 1998: 293). Although the preparation is so stressful that she soon regrets her hasty decision to become "a victim of a patriarchal illusion" (Gordon, 1998: 298), she willingly assumes her role as the hostess, and proves to be as graceful as Mrs. Ramsay by making sure that every guest is entertained. The result is a pleasing event, even more so than Mrs. Ramsay's dinner party, followed by a private time between the couple much happier than the Ramsays'. Evoking the final scene of "The Window" in Woolfs novel, in which Mr. Ramsay pesters his wife with a demand for her pledge of love after the feast (Woolf, 1955: 184), Monica's party culminates in B's toast to her: "To love and work" (Gordon, 1998: 300). This tribute strikes a peculiar note to her not only because he has never said he loves her before, but because, like Mrs. Ramsay, she is not "good at saying things to him. Or hearing them" (Gordon, 1998: 282). However, she accepts this tribute along with their bonding: "[T]here is something to all of it, this thing of being man and woman, for all its famous problems, all its varieties of grief" (Gordon, 1998: 300). If Mrs. Ramsay tactfully defuses her "grief" by concurring with her husband's objection to the trip to the lighthouse (Woolf, 1955: 186), Monica no longer feels constricted by her bonding with B. Rather, it releases her from her awkwardness with "saying things" to him, enabling her to extend her sincere gratitude for him after the party: "Thank you .... For everything” (Gordon, 1998: 300). By rewriting Mrs. Ramsay's diplomatic acquiescence to her husband's demand into Monica's heartfelt acknowledgement of her partner's generosity, Gordon negotiates a possible way for a woman artist to enjoy domestic bliss free from the "lie of 'the happy marriage" " (Rich, 1993: 198).

Ahmed suggests that happiness offers us a promise, which we glimpse in the unfolding of the present. But if we feel we have lost the possibility of happiness, then the future will embody that loss of possibility (2010: 160). This is exactly Lily Briscoe's emotion throughout To the Lighthouse. By contrast, Monica in her present happiness still looks forward to a happy future in her direct address to her audience toward the end of the novel. Imparting to the audience B's real name, Bernard, she is transported with joy over her "great love affair" (Gordon, 1998: 300-301). Bernard, in this way, sheds his function as the sex figure in Monica's erotica or the magical patron in her fairy tale of art economy; he becomes an intimate partner to share life with her in the years to come, in which each of them expend and at the same retain part of the self (Gordon, 1998: 301). Both erotic and serious, feminist and conventional, realist and fantastic, her life story evokes the commentary on Spent Men series: a combination of "wit and feeling" in a time of "postmodern ironic emptiness" (Gordon, 1998: 178). If she was surprised by the established art critic's praise of her paintings, she is now fully confident about her 
audience's sympathy (Gordon, 1998: 301). For her tale, like B's patronage, is a gift of love for innumerable women who dare not dream of having happiness in work and life. At times as surprising and thus risky as B's offer in its recourse to the fairy tale mode, her story of double happiness rends the established order to open spaces for "dreaming alternatives" (Warner, 1995: xvi).

This "difficult and perhaps impossible balancing act" (Sellers, 2001: 29) is ultimately Gordon's. Inspired by Woolf's economy for the woman artist, she pays tribute to her predecessor by rewriting To the Lighthouse into "A Utopian Divertimento", a happiness narrative marked by contingency and luck. By entering Woolf's texts from an alternative direction, Gordon delineates the possibility opened up by her unhappy predecessor, working toward a happier world for women artists.

\section{Notes}

1 Gordon was befriended by Margaret Drabble and Elizabeth Hardwick (White, 2002: 2).

\section{References}

Ahmed S (2010) The Promise of Happiness. Duke University Press: Durham, NC. Bell RH (1998) All expenses paid. Review of the Spending by Mary Gordon. Commonwealth, 10 April, pp 28-29.

Bennett A (1996) Mary Gordon. Twayne: New York.

Bromberg J (1999) Money, art and sex ... Gordon's novel has it all. Review of Spending by Mary Gordon. National Catholic Reporter, 7 May, p 33.

Cooperman JB (1999) The Broom Closet. Peter Lang: New York.

Corrigan M (1998) Monica gets it all. Review of Spending by Mary Gordon. The Nation, 10 March, pp 29-31.

Derrida J (1992) Given Time; translated by P. Kamuf. The University of Chicago Press: Chicago, IL.

DuPlessis RB (1985) Writing Beyond the Ending: Narrative Strategies of TwentiethCentury Women Writers. Indiana University Press: Bloomington, IN.

Emerson RW (1997) Gifts. In: Schrift AD (ed). The Logic of the Gift: Toward an Ethic of Generosity. Routledge: New York, pp 25-27.

Friedan B (1965) The Feminine Mystique. Penguin: Harmondsworth, UK.

Gordon M (1992) Good Boys and Dead Girls and other Essays. Penguin: New York.

Gordon M (ed) (1989) Foreword. In: A Room of One's Own. Harcourt: Orland, CA, pp vii-xiv.

Gordon M (1998) Spending. Scribner: New York.

Gundersheimer WL (1981) Patronage in the renaissance: An exploratory approach. In: Fitch LG and Orgel S (eds). Patronage in the Renaissance. Princeton University Press: Princeton, NJ, pp 3-23.

Hawley JC (1998) Review of Spending by Mary Gordon. America, 15 August, pp $20-22$.

Hope C (1981) Artists, patrons, and advisers In: Fitch LG and Orgel S (eds). Patronage in the Renaissance. Princeton University Press: Princeton, NJ, pp 293-343.

Hyde L (1979) The Gift: Imagination and the Erotic Life of Property. Vintage: New York
Janeson HW (1981) The birth of 'artistic license': The dissatisfied patron in the early renaissance. In: Fitch LG and Orgel S (eds). Patronage in the Renaissance. Princeton University Press: Princeton, NJ, pp 344-353.

Lee H (1999) Viginia woolf. Vintage: New York.

Malinowski B (1922) Argonauts of the Western Pacific. Routledge: London.

Macleod DS (1996) Art and the Victorian Middle Class: Money and the Making of Cultural Identity. Cambridge University Press: New York.

Mauss M (1990) The Gift: The Form and Reason for Exchange in Archaic Societies; translated by W. Halls. Routledge: London.

Review of Spending by Mary Gordon. (1997) Publishers Weekly, 24 November, p 50.

Rich A (1993) Women and honor: Some notes on lying. In: Gelpi B and Gelpi A (eds). Adrienne Rich's Poetry and Prose. Norton: New York, pp 195-203.

Ruether RR (2003) American Catholic feminism: A history. In: Ebest SB and Ebest $\mathrm{R}$ (eds). Reconciling Catholicism and Feminism?. University of Notre Dame Press: Notre Dame, IN, pp 8-12.

Sahlins MD (1974) Stone Age Economics. Tavistock: London.

Schuessler J (1998) Mary Gordon: Confessions of a good girl. Publishers Weekly, 9 March, pp 45-46.

Sellers S (2001) Myth and Fairy Tale in Contemporary Women's Fiction. Palgrave Macmillan: Basingstoke, UK.

Smith S (1998) Review of spending by Mary Gordon. Library Journal; 123 (1): 140

Warner M (1995) From the Beast to the Blonde: On Fairy Tales and their Tellers. Vintage: London.

White E (2002) Talking with Mary Gordon. In: Bennett A (ed). Conversations with Mary Gordon. University Press of Mississippi: Jackson, MS, pp 1-3.

Woolf V (1942) Professions for women. In: The Death of the Moth and other Essays. Harcourt Brace: San Diego, CA, pp 235-242.

Woolf V (1955) To the Lighthouse. Harcourt Brace: New York.

Woolf V (1989) In: Gordon M (ed). A Room of One's Own. Harcourt: Orland, CA.

\section{Data availability}

This paper does not analyse or generate any databases.

\section{Acknowledgements}

This article is part of a research project (NSC 98-2411-H-110-050-MY3). My heartfelt thanks go to my very capable research assistants, Yen-chi Wu, Tzu-yang Lin, and Wenhao $\mathrm{Xu}$, for invaluable aid in managing copious reading notes and research materials.

\section{Additional information}

Competing interests: The authors declare no competing financial interests.

Reprints and permission information is available at http://www.palgrave-journals.com/ pal/authors/rights_and_permissions.html

How to cite this article: Lin Y-C (2016) To the lighthouse revisited: the art economy in Mary Gordon's Spending. Palgrave Communications. 2:16067 doi: 10.1057/ palcomms.2016.67.

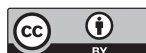

This work is licensed under a Creative Commons Attribution 4.0 International License. The images or other third party material in this article are included in the article's Creative Commons license, unless indicated otherwise in the credit line; if the material is not included under the Creative Commons license, users will need to obtain permission from the license holder to reproduce the material. To view a copy of this license, visit http://creativecommons.org/licenses/by/4.0/ 